JURNAL RISET REKAYASA ELEKTRO

Vol.2, No.1, Juni 2020, Hal. 10 16

P-ISSN: 2685 - $4341 \quad$ E-ISSN: 2685 - 5313

\title{
Rancang Bangun Pelampung Penyelamat Berbasis Remote Control
}

\author{
Moh. Edi Santoso ${ }^{1}$, Miftachul Ulum ${ }^{2}$, Achmad Fiqhi Ibadillah ${ }^{3}$ \\ Program Studi S1 Teknik Elektro, Universitas Trunojoyo Madura \\ Fakultas Teknik, Universitas Trunojoyo Madura
}

\section{Informasi Makalah}

Dikirim, 11 Maret 2020

Direvisi, 17 Juni 2020

Diterima, 30 Juni 2020

\section{Kata Kunci:}

Pelampung

Remote Control

Motor DC Brushless

NFR24L01

\begin{abstract}
INTISARI
Perkembangan teknologi mendorong terciptanya alat yang semula bersifat tradisional menjadi modern dan canggih, sehingga memudahkan manusia dalam menjalankan pekerjaannya. Pada penelitian ini penulis akan membuat pelampung penyelamat yang dapat menolong korban yang akan tenggelam dengan cara menjemput korban kemudian membawanya ke tepi. Pelampung penyelamat ini terbuat dari bahan plastik atau sejenisnya sebagai body pelampung agar tetap dapat mengapung meskipun diberi muatan. Sebagai penggeraknya pelampung ini menggunakan dua buah motor DC brushless yang dimodifikasi sedemikian rupa sehingga dapat berfungsi sebagai balingbaling. Pelampung penyelamat ini dikendalikan menggunakan remot kontrol oleh user dalam misinya menyelamatkan korban. Komunikasi antara remot kontrol dengan pelampung penyelamat menggunakan jaringan wireless yakni menggunakan NRF24L01 yang berfungsi untuk proses pengiriman data, adapun proses tersebut menggunakan antena pemancar sebagai penguat sinyal. Alat ini menggunakan mikrokontroler nodeMCU sebagai pusat kontrol untuk proses input dan output data. Pelampung ini mampu melaju dengan kecepatan $0,75-1 \mathrm{~m} / \mathrm{s}$ dalam kondisi tanpa beban dan $0,3 \mathrm{~m} / \mathrm{s}$ dalam kondisi dengan beban seberat $50 \mathrm{~kg}$ di udara.
\end{abstract}

\begin{abstract}
The development of technology encourages the creation of tools that were originally traditional in nature to be modernand shophisticated, sho that is will facilitate humans in carriying out their work. in this research, the writer will make a live vest that can help victims who will drown by picking up victim and then bringing it to the edge. this life jacket is made of plastic or the like as a buaoy body so that it can float even though it isloaded. as a propulsion, this buoy uses two brushless DC motors that are modified in such a way that it can function as a propeller. this life jacket is controlled using a remote control by the user in his mission to save the victim. communication between the remote and the life buoy using a wireless network thwt uses NRH24L01 which functions for the procces of sending data, while the procces uses a transmitting antenna as a signal amplifier. this tool uses a nodeMCU microcontroller as a control center for the procces of input and output data. This buoy is able to go with the speed of $0.55-1 \mathrm{~m} / \mathrm{s}$ in no-load conditions and $0.3 \mathrm{~m} / \mathrm{s}$ in conditions with loads weighing $50 \mathrm{~kg}$ in the air.
\end{abstract}

\section{Korespondensi Penulis:}

Mohammad Edi Santoso, Miftachul Ulum, Achmad Fiqhi Ibadillah

Program Studi Teknik Elektro

Fakultas Teknik Universitas Trunojoyo Madura

JL. Raya Telang Indah, Kamal, Bangkalan, 69162

Email: edyfals.27@gmail.com, miftachul.ulum@trunojoyo.ac.id, fiqhi.ibadillah@trunojoyo.ac.id 


\section{PENDAHULUAN}

Di zaman yang semakin modern ini perkembangan teknologi berjalan sangat cepat, perkembangan teknologi mengubah alat yang semula bersifat manual menjadi lebih modern. Hal ini memudahkan manusia dalam menjalankan pekerjaannya sehingga pekerjaan menjadi lebih cepat dan hasil pekerjaan lebih maksimal. Teknologi yang canggih juga dapat mencegah atau mengurangi resiko timbulnya korban ketika orang bekerja. Pada bidang pariwisata khususnya pada alat-alat keselamatan, perkembangan teknologi juga dibutuhkan untuk mencegah jatuhnya korban kecelakaan saat berwisata. Pada wisata air misalnya wisata kolam renang diperlukan adanya pelampung keselamatan yang canggih dan modern, sehingga dapat mencegah jatuhnya korban jiwa akibat tenggelam.

Pelampung penyelamat berbasis remote control merupakan hasil modifikasi dari pelampung manual yang telah ada, yang ditambahkan dengan rangkaian elektronika dan dilengkapi dengan sistem kontrol serta sistem komunikasi. Pelampung akan menjemput dan mengangkut korban yang akan tenggelam dengan cara dikendalikan menggunkan remot kontrol. Setelah korban terangkut pelampung akan membawa korban menuju ke tepi. Komunikasi antara pelampung dan remot kontrol menggunakan jaringan wireless. Pelampung ini merupakan solusi dari permasalahan kurang cepatnya pertolongan pada korban tenggelam karena masih menggunakan pelampung manual. Dengan adanya pelampung penyelamat yang lebih canggih diharapkan tidak ada lagi korban tenggelam karena pertolongan yang lebih cepat dan lebih efektif.

Berdasarkan dari uraian permasalahan diatas, penulis akan membuat sebuah pelampung penyelamat berbasis remote control yang dapat menolong korban yang akan tenggelam, sehingga korban tidak sampai tenggelam dan dapat diselamatkan. Pelampung penyelamat ini menggunakan remote control yang dikendalikan oleh user dalam melakukan misi penyelamatan dan menggunakan jaringan wireless sebagai komunikasi antara remote control dan pelampung.

\section{METODE PENELITIAN}

Pada penelitian ini dilakukan pengumpulan sumber referensi yang berkaitan dengan penelitian baik melalui jurnal, buku, maupun media elektronik. Selanjutnya dilakukan perancangan hardware dan software, perancangan hardware meliputi pelampung beserta rangkaian elektronikanya sedangkan perancangan software terdiri atas pemograman mikrokontroler. Tahap selanjutnya dilakukan pengujian alat yang bertujuan untuk mengetahui kinerja alat, lalu dilakukan pengumpulan data hasil uji coba. Selanjutnya data tersebut dievaluasi untuk mendapatkan kesimpulan dari hasil uji coba alat tersebut.

\subsection{Diagram Alur Sistem}

Pada sistem pelampung penyelamat berbasis remote kontrol ini terdapat tiga bagian, yakni input, kontrol, dan output. Bagian input berupa joystick, bagian kontrol adalah mikrokontroler nodemcu, dan bagian output berupa motor dc brushless. Berikut diagram alur sistem yang dapat dilihat pada gambar 2.1

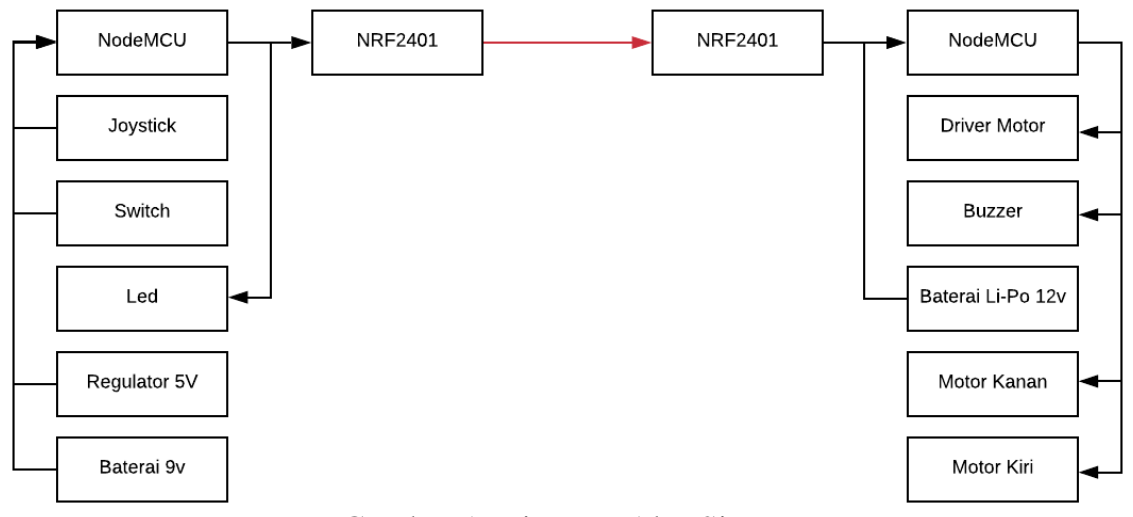

Gambar 1. Diagram Alur Sistem

Pada gambar 1 merupakan diagram alur sistem yang terdiri dari beberapa perangkat input, proses, dan output. Berikut penjelasan dari masing-masing perangkat tersebut.

1. NodeMCU

NodeMCU pada alat ini berfungsi sebagai pusat control untuk proses input dan output.

2. Joystick

Joystick digunakan untuk proses input data berupa perintah untuk mengarahkan pelampung.

3. Baterai 12 volt 
Digunakan untuk mensuplai daya pada pelampung sehingga pelampung dapat berjalan ke arah tujuan.

4. NRF24101

Adapun fungsi NRF24 adalah untuk proses pengiriman data dengan media komunikasi wireless. Proses tersebut menggunakan antenna pemancar sebagai penguat sinyal.

5. Driver Motor

Driver motor digunakan untuk mengatur putaran motor kanan dan motor kiri sehingga pelampung dapat berbelok ke kanan dan ke kiri.

6. Motor Brushless DC

Motor Brushless DC digunakan untuk memutar baling-baling pada pelampung sehingga pelampung dapat berjalan sesuai yang diinginkan

7. Buzzer

Buzzer digunakan untuk informasi berupa suara sehingga pengguna dapat mendengarkan informasi pelampung dengan suara. Informasi tersebut berupa informasi baterai habis atau baterai penuh.

\subsection{Desain Sistem}

Pada desain sistem penelitian ini terdapat 2 desain, yaitu desain sistem untuk remot kontrol dan desain sistem untuk pelampung. Desain sistem dapat dilihat pada gambar dibawah ini, gambar 2 desain sistem untuk pelampung dan gambar 3 desain sistem untuk remot kontrol.

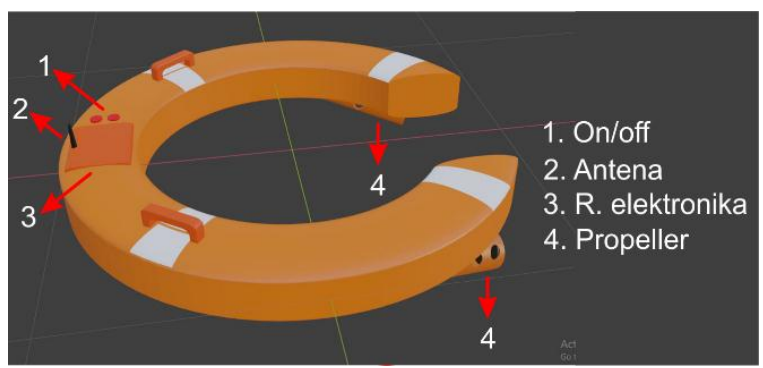

Gambar 2. Desain Pelampung

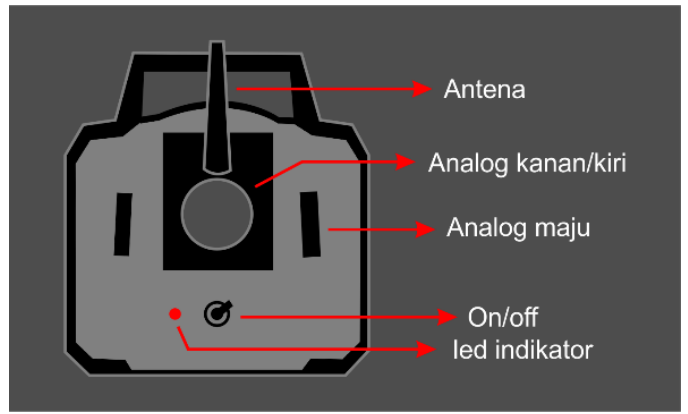

Gambar 3. Desain Remot kontrol

\subsection{Rangkaian Elekronika}

Berdasarkan kebutuhan sistem pada penelitian ini, berikut ini rangkaian elektronika pada pelampung dan remot kontrol yang dapat dilihat pada gambar dibawah ini. Gambar 4 rangkaian elektronika pada remot kontrol (transmitter) dan gambar 5 rangkaian elektronika pada pelampung (receiver).

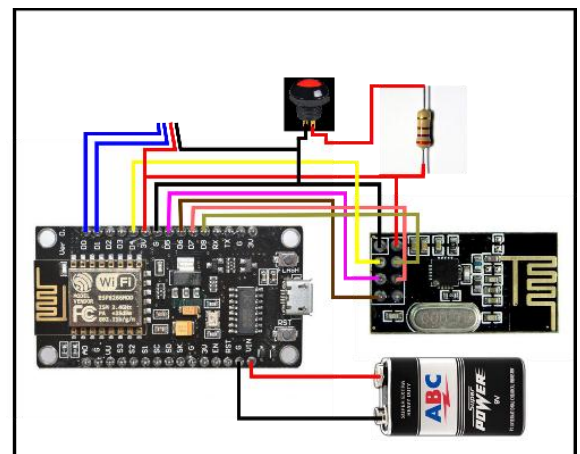

Gambar 4. Skema Transmitter (remot kontrol)

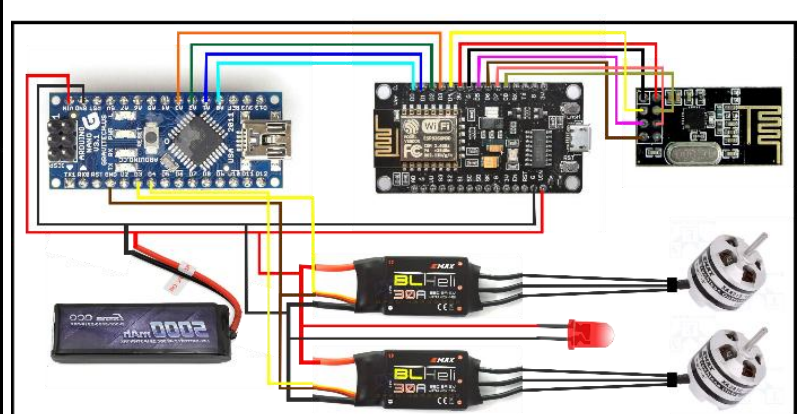

Gambar 5. Skema Receiver (pelampung)

Pada gambar 4 transmitter, merupakan rangkaian elektronik yang ada pada remot kontrol yang berfungsi untuk mengontrol pergerakan pelampung saat menjalankan misi penyelematan. Pada rangkaian tersebut terdiri dari beberapa komponen utama, antara lain Joystick digunakan sebagai proses input data pada mikrokontroler berupa perintah untuk mengarahkan pelampung ke kanan, ke kiri, dan maju. NodeMCU berfungsi sebagai otak atau pusat control untuk proses input dan output pada rangkaian. Modul nrf24101 untuk proses pengiriman data dengan media komunikasi wireless, proses tersebut menggunakan antena pemancar sebagai penguat sinyal.. Push button berfungsi sebagai saklar on/off untuk memutus atau mengalirkan tegangan. Dan baterai berfungsi untuk mensuplai daya pada rangkain. 
Pada gambar 5 receiver, merupakan rangkaian elektronik yang ada pada pelampung, pelampung berfungsi untuk mengangkut korban. Pada rangkaian ini terdiri dari komponen-komponen utama, seperti modul nrf24101 yang berfungsi untuk komunikasi antara pelampung dengan remot kontrol, data yang dikirim oleh remot kontrol diterima oleh pelampung melalui komunikasi antar modul nrf24101. NodeMCU digunakan untuk mengolah input data yang diterima oleh pelampung dari remot kontrol. Arduino nano digunakan sebagai pendukung dari nodeMCU untuk memberikan input pada ESC, ESC digunakan untuk mengatur putaran motor dc brushless. Motor dc brushless berfungsi untuk memutar propeller, propeller berperan sebagai penggerak pelampung sehingga pelampung dapat berjalan menghampiri korban. Led digunakan sebagai indikator pengiriman data, saat data dari remot kontrol berhasil dikirim maka led akan aktif. Baterai li-po digunakan untuk mensuplai daya pada rangkaian.

\section{HASIL DAN PEMBAHASAN}

Pengujian alat dan pengambilan data uji coba dilakukan setelah proses perancangan alat selesai. Berikut ini merupakan data hasil pengujian serta pembahasannya pada alat yang telah selesai dibuat dan dilakukan percobaan.

\subsection{Hasil Pengujian NodeMCU}

Pengujian nodeMCU bertujuan untuk memastikan nodeMCU yang digunakan pada penelitian tidak mengalami kerusakan dan kegagalan pada saat mengeksekusi program, sehingga pada saat nodeMCU digunakan dapat berjalan dengan baik dan lancar.

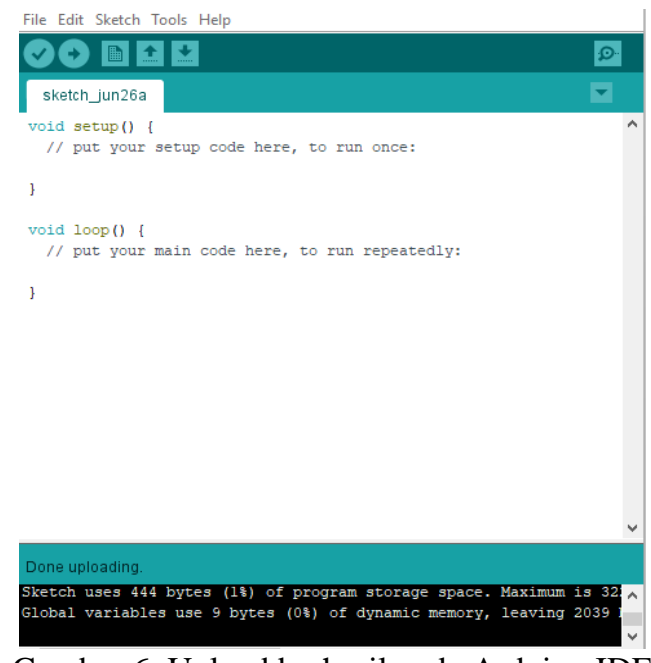

Gambar 6. Upload berhasil pada Arduino IDE

Pada gambar 6 diatas merupakan proses pengujian program pada nodeMCU dengan software Arduino ide, tulisan "done uploading" menandakan program yang ditulis telah benar dan berhasil di-upload pada nodeMCU

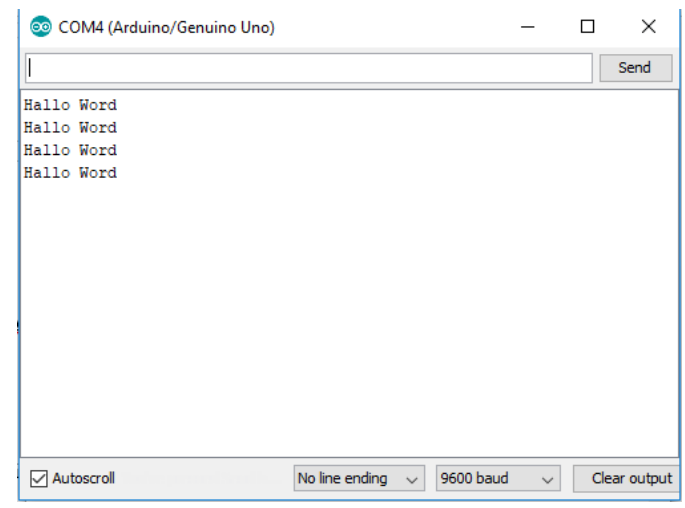

Gambar 7. Tampilan pada serial monitor 
Pada gambar 7 diatas menunjukkan bahwa data yang dikirim pada serial monitor sesuai dengan program perintah yang dibuat dan di-upload pada nodeMCU. Dengan begitu nodeMCU ini dapat bekerja dengan baik dan dapat digunakan dalam pembuatan sistem.

Table 1 Data hasil pengujian Vinput nodeMCU

\begin{tabular}{ccc}
\hline No & Pengukuran pada port & Hasil pengukuran tegangan volt DC \\
\hline 1 & Vinput Digital & 4.98 Volt DC \\
2 & Vinput Analog & 4.98 Volt DC \\
\hline
\end{tabular}

Selain itu juga dilakukan pengujian pada Vinput I/O pada nodeMCU tersebut dengan menggunakan multimeter. Tabel 1 diatas merupakan hasil pengukuran Vinput I/O pada nodeMCU, dimana diperoleh ratarata tegangan keluaran pada Vinput sebesar 4,98 VDC. Sehingga dapat dipastikan nodeMCU dapat bekerja dengan baik karena nodeMCU memerlukan input tegangan 4,5 - 5,5 VDC.

\subsection{Hasil Pengujian Transmisi Data NRF24L01}

Pengujian transmisi data NRF24L01 bertujuan untuk mengukur jarak jangkauan antara remot kontrol dengan pelampung.

Table 2 Hasil pengujian transmisi data NRF24L01

\begin{tabular}{ccc}
\hline Jarak Pengujian $(\mathbf{m})$ & Lampu Led & Keterangan \\
\hline 10 & Aktif & Berhasil \\
20 & Aktif & Berhasil \\
30 & Aktif & Berhasil \\
40 & Aktif & Berhasil \\
50 & Aktif & Berhasil \\
60 & Aktif & Berhasil \\
70 & Aktif & Berhasil \\
80 & Aktif & Berhasil \\
90 & Aktif & Berhasil \\
100 & Aktif & Berhasil \\
\hline
\end{tabular}

Pengujian dilakukan pada jarak 10 meter hingga jarak 100 meter. Pada tabel 2 hasil pengujian transmisi data NRF24L01 diatas menunjukkan bahwa pengujian berhasil yang ditandai dengan led yang menyala.

\subsection{Hasil Pengujian Perangkat I/O Remot Kontrol}

Pengujian perangkat I/O terdapat 3 perangkat yang diujikan, yaitu limit switch untuk input arah maju, joystick untuk input belok kanan dan kiri, dan NRF24L01 untuk pengiriman data pada pelampung.

Tabel 3 Hasil pengujian perangkat I/O remot kontrol

\begin{tabular}{cccc}
\hline Percobaan & Limit Switch & Joystick & NRF2401 \\
\hline 1 & ON & OFF & Kirim data '1' \\
2 & $O F F$ & Kanan & Kirim data '2' \\
3 & $O F F$ & Kiri & Kirim data '3' \\
4 & $O F F$ & $O F F$ & Kirim data '0' \\
\hline
\end{tabular}

Pada tabel 3 Hasil pengujian perangkat I/O remot kontrol diatas menunjukkan jika limit switch on maka data yang dikirim pada NRF24L01 adalah ' 1 '. Jika Joystick kanan $O N$ maka data yang dikirimkan pada NRF2401 adalah '2'. Jika Joystick kiri $O N$ maka data yang dikirimkan pada NRF2401 adalah '3'. Jika semua OFF maka data yang dikirimkan pada NRF2401 adalah ' 0 '.

\subsection{Hasil Pengujian Perangkat I/O Pelampung}

Pengujian perangkat I/O pelampung meliputi pengujian NRF24L01, motor kanan, dan motor kiri. NRF24L01 digunakan untuk penerimaan data pada pelampung yng dikirimkan oleh remot kontrol. 
Table 4 Hasil pengujian perangkat I/O pelampung

\begin{tabular}{cccc}
\hline Percobaan & NRF2401 & Motor Kanan & Motor Kiri \\
\hline 1 & Terima data ' 1 ' & ON & ON \\
2 & Terima data '2' & OFF & ON \\
3 & Terima data '3' & ON & OFF \\
4 & Terima data '0' & OFF & OFF \\
\hline
\end{tabular}

Pada Tabel 4 hasil pengujian perangkat I/O pelampung diatas dapat dilihat bahwa jika data adalah ' 1 ' maka kedua motor $O N$. Jika data adalah ' 2 ' maka motor kanan $O N$. Jika data adalah ' 3 ' maka motor kiri $O N$. Jika data adalah '0' maka semua.

\subsection{Hasil Pengujian Alat Tanpa Beban}

Pengujian alat secara keseluruhan ini meliputi pengujian remot kontrol dan pelampung, pengujian dilakukan di kolam renang atau danau tanpa menggunakan beban dapat dilihat seperti pada gambar 8 .

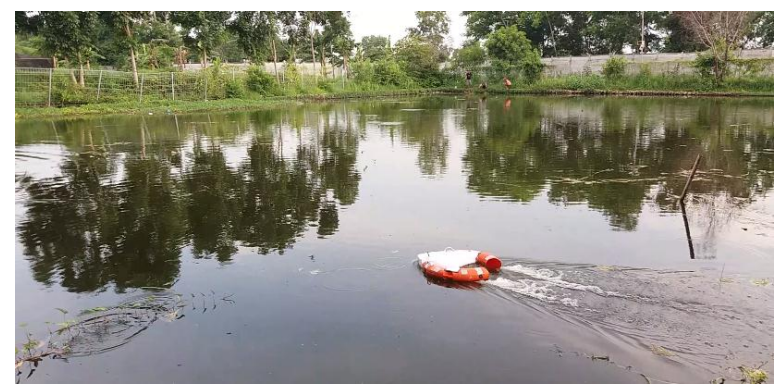

Gambar 8. Pengujian alat tanpa beban

Tabel 5 Hasil pengujian keseluruhan alat tanpa beban

\begin{tabular}{ccc}
\hline Remot Kontrol & Pergerakan Pelampung & Keterangan \\
\hline Switch & Maju & Sesuai \\
Analog ke kanan & Belok kanan & Sesuai \\
Analog ke kiri & Belok kiri & Sesuai \\
Analog ke depan & Maju kecepatan penuh & Sesuai \\
\hline
\end{tabular}

Pada tabel 5 hasil pengujian keseluruhan alat tanpa beban diatas dapat dilihat pada saat switch maju pelampung berjalan maju, saat analog joystick diarahkan ke kanan pelampung belok ke kanan, saat analog joystick diarahkan ke kiri pelampung belok ke kiri, dan saat analog joystick diarahkan ke depan pelampung melaju ke depan dengan kecepatan penuh, hal ini menunjukkan bahwa alat berjalan sesuai dengan baik. Pada kondisi tanpa beban pelampung dapat melaju dengan kecepatan rata-rata 0,75 - 1 meter perdetik

\subsection{Hasil Pengujian Alat Dengan Beban}

Sama halnya pada pengujian alat tanpa beban, pengujian alat kali ini juga meliputi pengujian pelampung dan remot kontrol, hanya saja pada pengujian ini ditambahkan beban pada pelampung. Pengujian juga dilakukan di danau atau di kolam renang, dapat dilihat pada gambar 9.

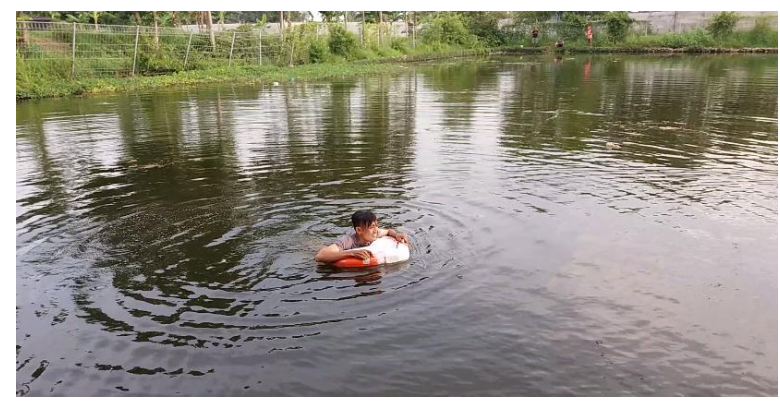

Gambar 9 Pengujian alat dengan beban 


\begin{tabular}{ccc} 
& \multicolumn{2}{c}{ Tabel 6 Hasil pengujian Alat dengan beban } \\
\hline Remot Kontrol & Pergerakan Pelampung & Keterangan \\
\hline Switch & Maju & Sesuai \\
Analog ke kanan & Belok kanan & Sesuai \\
Analog ke kiri & Belok kiri & Sesuai \\
Analog ke depan & Maju kecepatan penuh & Sesuai \\
\hline
\end{tabular}

Pada tabel 6 hasil pengujian keseluruhan alat tanpa beban diatas dapat dilihat pada saat switch maju pelampung berjalan maju, saat analog joystick diarahkan ke kanan pelampung belok ke kanan, saat analog joystick diarahkan ke kiri pelampung belok ke kiri, dan saat analog joystick diarahkan ke depan pelampung melaju ke depan dengan kecepatan penuh, hal ini menunjukkan bahwa alat berjalan sesuai dengan baik. Pada kondisi dengan beban pelampung dapat melaju dengan kecepatan rata-rata 0,3 meter perdetik.

\section{KESIMPULAN}

Berdasarkan dari hasil pengujian alat yang telah dilakukan pada penelitian ini dapat diambil beberapa kesimpulan, antara lain:

1. Komunikasi data antara nodeMCU dengan NRF24L01 menggunakan pengiriman serial, sehingga pin yang digunakan adalah Rx dan Tx. NRF24L01 digunakan untuk pengiriman data dengan 1 jalur transmisi data. Jarak maksimal yang digunakan pada pengujian 100 meter dengan presentase keberhasilan $100 \%$.

2. Pengiriman data antara remot control dengan pelampung dapat berjalan dengan baik sesuai dengan perintah remot kontrol. Tingkat keberhasilan pada pengujian sebesar $100 \%$

3. Pada percobaan alat tanpa beban pelampung melaju dengan kecepatan rata-rata 0,75 - 1 meter perdetik, sedangkan pada kondisi dengan beban pelampung melaju dengan kecepatan 0,3 meter perdetik.

\section{DAFTAR PUSTAKA}

[1] Upik Jamil Sabrina, Rakhmandy Primananda, dan Rizal Maulana, "Analisis Kinerja Pengiriman Data Modul Transceiver NRF24101, Xbee, dan Wifi ESP8266 pada Wireless Sensor Network,” Jurnal Pembangunan Teknologi Informasi dan Ilmu Komputer, Vol. 2, No. 4, 2018.

[2] Fadli Sirait dan Billy Aji Wicaksono, "Prototype Smart Life Jacket Berbasis Arduino," Jurnal Teknologi Elektro Universitas Mercu Buana, Vol. 8, No. 2, 2017.

[3] Musa Albana, Rona Rianti, dan Li Munadhif, "Perancangan dan Pembuatan Prototype Remote Control Buoys Bertenaga Baterai dengan actuator Propeller," Proceeeding $2^{\text {nd }}$ Conferences On Safety Engineering, No. 2581, pp. 75-80, 2015 .

[4] Ari Sugiharto dan Sri Windiyanti, "Rancang Bangun Robot Pengintai dengan Kendali Android," Prosiding Seminar Ilmu Nasional, pp. 1-13, 2017.

[5] Muhamad Yusvin Mustar, Aditiyo Eka Nugroho, Ahmad Imam Hidayat, dkk, "Rancang Bangun Robot Amphibi Sebagai Sistem Monitoring Gorong-gorong,”Jurnal Ilmiah Semesta Teknika, Vol. 20, No. 2, 2017.

[6] Deni Achmad Soeboer, Budhi H. Iskandar, Indra Jaya, dkk, "Rancang Bangun Pelampung Pelacak Arus Permukaan Menggunakan Instrumen GPS," ALBACORE, Vol. 2, No. 3, 2018.

[7] Albaladejo Pérez, H. N. Hellín, F. S. Valles, A. I. García, and R. Torres, "Low Cost Buoy for Monitoring Recreational Areas," Sixth Int. Work. Mar. Technol. Martech, pp. 143-146, 2015.

[8] A. R. S and V. Venkatesh, "Implementation of Wireless Sensor Network with Low Cost and Low Power using Arduino and nRF24L01," vol. 119, no. 18, pp. 2095-2103, 2018.

[9] M. Mahbub, “Automated control signal reception acknowledgement system using nRF24L01P wireless transceiver module and Arduino," ICST Trans. Mob. Commun. Appl., vol. 5, no. 16, p. 159337, 2019.

[10] M. Mahbub, "Design and Implementation of Multipurpose Radio Controller Unit Using nRF24L01 Wireless Transceiver Module and Arduino as MCU Design and Implementation of Multipurpose Radio Controller Unit Using nRF24L01 Wireless Transceiver Module and Arduino as MCU," Int. J. Digit. Inf. Wirel. Commun., no. September, 2019. 